\title{
REKONTRUKSI PEMBELAJARAN SEJARAH DALAM MENGHADAPI \\ ERA REVOLUSI 4.0 DI UNIVERSITAS SYIAH KUALA
}

\author{
Nurasiah, Abdul Azis \\ Email: nurasiah.sjh@fkip.unsyiah.ac.id \\ Jurusan Sejarah Universitas Syiah Kuala
}

\begin{abstract}
Abstrak
Pembelajaran sejarah merupakan salah satu kajian ilmu yang mengkaji secara keseluruhan manusia sebagai mahluk yang berkebudayaan tinggi. Pembelajaran sejarah juga membahas nilainilai karakter yang unik. Adapun dewasa ini, pembelajaran sejarah menghadapi tantantang baru yaitu berkembangnya Revolusi Industri 4.0. Revolusi industri 4.0, sudah mulai menetrasi berbagai aspekkehidupan, dan tatanan sosial. Dunia pendidikan nasional kususnya pembelajaran sejarah, tidak memiliki pilihanselain merespon tantangan tersebut. Revolusi Industri 4.0 merupakan revolusiindustri keempat dan hadir setelah terjadi revolusi industri pertama denganditemukannya mesin uap. Revolusi industri kedua yang berkaitan dengan listrik,revolusi industri ketiga yang serba komputerisasi. Revolusi industri 4.0 ditandaiperkembangan teknologi dan informasi yang moderen. Di era RevolusiIndustri 4.0, mahasiswa harus berani keluar dari zona innyaman selama ini.Melanjutkan pendidikan di perguruan tinggi tidak hanya diarahkan pada tataranto be (belajar menemukan jati diri), to know (belajar untuk tahu), dan to $d o$ (mengaplikasikan pengetahuan pada kehidupan yang nyata) tetapi lebih dari itumenjangkau pada to live together (belajar membentuk sikap hidup dalamkebersamaan). Di era Revolusi Industri 4.0 Prodi pendidikan sejarah dituntut untukmeluluskan mahasiswa yang memiliki kemampuan adaptif terhadap perubahanyang sering terjadi. Kemampuan tersebut antara lain meliputi kemampuanmenyelesaikan masalah yang makin kompleks, berpikir kritis, kreatif, inovatif serta mampumenjadi lulusan yang ber pengetahuan yang tinnggi, serta memiliki kemampuan koordinasi yang baik.Lulusan program studi pendidikan sejarah diharapkan harus memilikiemotional intellegenceyang baik, kemampuan skill yang bagus, serta kemampuan dalam bersaing secara adaptif.
\end{abstract}

Kata Kunci: Rekonstruksi, Pembelajaran sejarah, Era revolusi 4.0, Universias Syiah Kuala

\section{Pendahuluan}

Menghadapi era revolusi industri 4.0 , peran prodi pendidikan sejarah menjadi sangat penting, terutama dalam perkembangannya ilmu pengetahuan dan teknologi. Oleh karenanya, pendidikan sejarah yang berbasis riset harus mendorong semakin terbukanya pengetahuan yang mampu meningkatkan kesejahteraan, toleransi serta terciptanya budaya multikulturalisme didalam masyarakat. Di era revolusi 4.0 sekarang ini, banyaknya kasus intoleransi didalam berbagai media sosial sehingga mengakibatkan krisis keberagaman didalam masyarakat Indonesia. 
Era rovolusi 4.0 kuantitas bukan lagi menjadi indikator utama bagi suatu perguruan tinggi dalam mencapai kesuksesan, melainkan kualitas lulusannya. Kesuksesan sebuah negara dalam menghadapi revolusi industri 4.0 erat kaitannya dengan inovasi yang diciptakan oleh sumber daya yang berkualitas, sehingga seluruh Perguruan Tinggi kususnya program studi pendidikan sejarah wajib dapat menjawab tantangan untuk menghadapi kemajuan teknologi dan persaingan dunia kerja di era globalisasi.

Dalam menciptakan sumber daya yang inovatif dan adaptif terhadap teknologi, diperlukan penyesuaian sarana dan prasarana pembelajaran dalam hal teknologi informasi, internet, analisis bigdata dan komputerisasi. Perguruan tinggi kususnya program studi pendidikan sejarah yang menyediakan infrastruktur pembelajaran tersebut diharapkan mampu menghasilkan lulusan yang terampil dalam aspek literasi data, literasi teknologi dan literasi manusia. Terobosan inovasi akan berujung pada peningkatan produktivitas manusia, industri dan melahirkan berbagai kajian materi berbasis digital teknologi, seperti yang banyak bermunculan di Indonesia saat ini.

Tantangan berikutnya adalah rekonstruksi kurikulum pembelajaran sejarah yang responsif terhadap revolusi industri juga diperlukan, seperti desain ulang kurikulum dengan pendekatan human digital dan keahlian berbasis digital. Sistem perkuliahan berbasis teknologi informasi nantinya diharapkan menjadi solusi bagi anak bangsa di pelosok daerah untuk menjangkau pendidikan tinggi yang berkualitas. Persiapan dalam menghasilkan lulusan yang mampu beradaptasi dengan Revolusi Industri 4.0 adalah salah satu cara yang dapat dilakukan Perguruan Tinggi untuk meningkatkan daya saing terhadap kompetitor dan daya tarik bagi calon mahasiswa. Berbagai tantangan sudah hadir didepan mata, sudah siapkah Perguruan Tinggi kususnya program studi pendidikan sejarah menyiapkan generasi penerus bangsa di era Revolusi Industri 4.0dan persaingan global?

\section{Metode Penelitian}

Metode yang digunakan dalam penulisan prosiding ini adalah libraryresearch dengan analisis deskriptif. Dalam proses kegiatan analisa deskriptif penulis melakukan kegiatan mempelajari alat, teknik, atau prosedur yang digunakan untuk mendeskripsikan kumpulan data atau hasil pengamatan yang telah dilakukan. Kegiatan-kegiatan tersebut antara lain adalah kegiatan pengumpulan data, pengelompokkan data, penentuan nilai, analisis dan kesimpulan. 


\section{Hasil dan Pembahasan}

\section{A. Pengertian Pembelajaran Sejarah}

Sejarah adalah rekontruksi the human past untuk mengetahui, memahami, dan mengambil pelajaran dari berbagai peristiwa dan aspek-aspek penting di masa lampau berdasarkan facta dan bukri-bukti terkait (Florovsky, 1969). Aktivitas dan perkembangan manusia baik dalam bentuk peristiwa, pemikiran, mentalitas, intektualitas di masa lalu yang bermakna sosial direkonstruksi untuk kepentingan masa kini dan masa depan (Kuntowijoyo, 2013: 10-14). Dengan demikian, sejarah berfungsi untuk memperjelas masa lalu dan mampu menjelaskan berbagai peristiwa dan maknanya secara jelas. Faktor tersebut penting sebagai bentuk kekuatan dan kepaduan masyarakat yang menjadi unsur utama dalam keberhasilan dan efektivitas masyarakat (Rowse, 2014: 186).

Rekonstruksi masa lalu dilakukan untuk memenuhi suatu rasa ingin tahu mengenai masa lampau, hasrat untu menerangkan asal usul budaya, semangat patriotik kepada asal usul negeri, kehendak untuk mengerti latar belakang sosial dan suasana intelektual. Suatu pencarian untuk menemukan "pelajaran sejarah" yang akan membantu manusia zaman sekarang untuk memecahkan masalah-masalahnya yang sekarang, keinginan untuk menemukan di dalam bacaan sejarah ilustrasi-ilustrasi yang efektif bagi pencocokan dari suatu argumen atau suatu generalisasi. Pendalaman mengenai suatu metode pada masa lampau untuk masalampau sendiri (Gottschalk, 2008: 138).

Dimensi tempooral sejarah dengan demikian mencakup masa lalu, masa kini dan masa depan. Sejarah tidak hanya semata-mata mempelajari masa lalu atau bersifat antikuarin. Sejarah merupakan proses interaksi kontinu antara sejarawan dengan fakta-faktanya, dialog tanpa akhir antara masa kini dan masa lalu (Carr, 2014; 35). Sejarah merupakan sumber inspirasi dan pengalaman dimana hal tersebut mendasari aksi bijak untuk memahami kondisi realitas kekinian yang dialami individu (Daniels, 2981: 6-8).

Sejarah merupakan rangkaian kejadian yang berkausalitas pada masyarakat manusia dengan segala aspeknya serta proses gerak perkembanganya yang kontinu dari awal sejarah hingga kini berguna bagi pedoman kehidupan masyarakat masa sekarang serta arah cita-cita masa depan (Sjamsuddin \& Ismaun, 1993: 5). Masa lalu hanya dapat kita pahami dengan jelas dari sudut pandang masa kni, dan kita dapa benar-benar memahami masa kini hanya dari sudut 
pandang masa lalu. Mungkinkan manusia memahami masyarakat masa lalu dan meningkatkan penguasaanya terhadap masa kini adalah fungsi ganda dari sejarah (Carr, 2014: 71).

Dalam kaitanya dengan lintasan waktu masa lalu, masa kini dan masa depan, sejarah merupakan aktivitas mewariskan ingatan dan menyamai kesadaran jati diri yang membantu individu atau masyarakat masa kini untuk memahami realitas sosial kontemporer. Rekontruksi sejarah dapat disebut sebagai kilasan sejarah sesaat atau instant history yang teruh menerus direproduksi untuk kepentingan masa kini. Melalui kilasan sejarah, masyarakat kontemporer membangun pemahaman, ingatan sejarah dan jati diri dalam konstek kehidupannya di masa kini dan masa mendatang. Hal ini menjadi penting, khususnya bagi genetasi kekinian yang tidak mengalami langsung kejadian-kejadian sejarah (Gillis, 1994: 3).

Dalam konstek sejarah, tujuan dalam memahami masa lalu adalah menjadi manusia yang bijak atau wise atau bijak dalam masa kini dan masa depan. Proses menuju individu atau masyarakat menuju wise dapat melalui pengambilan aspek nilai dan hikmah dari peristiwa yang terjadi di masa lalu (A.L. Rowse, 2014: 168). Dengan demikian, melalui sejarah dapat ditekankan proses pendidikan nilai. karakter merupakan pedoman ataupun konsepsi ideal yang mengarahkan kebiasaan dan keputusan serta membantu suatu individu atau masyarakat dalam menentukan baik atau buruknya suatu dala kategori monadic (baik,buruk,sangat buruk) ataupun dyadic (lebih baik, lebih buruk dan seimbang) (Hansson, 2004: 15). Keberadaan karakter dalam konstruk diri seseorang individu akan membentuk kesadaran dalam membangun perbuatan, sikap ataupun keputusan yang baik. karakter juga berperan penting dalam membangun kerangka interaksi dan kehidupan sosial yang mencakup enam kerangka tujuan yaitu: (1) nilai bagi diri sendiri; (2) orang lain; (3) lingkungan; (4) pengetahuan ;(5)m potensi; dan (6) komunitas (Koutsaukis, 2009: iv-vii).

Nilai yang didapat tersebut tidak hanya digunakan untuk menganalisis dan menilai peristiwa yang terjadi di masa lampau. Penilaian masa lalu dengan patokan dan ukuran nilai mas akini akan menyulit peserta didik untuk memahami konteks sejarah (Barton \& Levstik, 2004:101) akibat dari kesalahan pemahaman dan penggunakan ukuran niali mas akini untuk menilai suatu peristiwa atau fenomena yang terjadi masa lalu tersebut akan menimbulkan kesalahan historis (Fischer, 1970). Dengan demikian, idealnya nilai digunakan untuk mengkonstruksi dimasa kini dan masa depan. 
Nilai dan hikmah tersebut didapat melalui interpretasi untuk memahami (verstehen) makna dari sejarah di masa kini (Palmer, 120:139). Interpretasi masa lalu perlu diikuti oleh keahlian reflektif untuk membuka kesadaran serta pemahaman kesejarahan menuju tahap relational dan extended. Pemahaman sejarah relational berada dalam tahap dimana peserta didik memahami, membandingkan dan mempertentangkan beragam interpretasi sejarah untuk kemudian menghasilkan kesimpulan mandiri. Sementara itu, pemahaman sejarah extended berada dalam mtaham dimana peserta didik melihat perbedaan perspektif dari masa lalu dan masa depan sebagai produk dari perbedaan konsep ide dan idealisasi (Phillips, 2008:17). Interpretasi dan refleksi terhadap masa lampau akan membuka kesadarn serat kemampuan tumbuhnya tujuan-tujuan baru ke masa depan (Kochhar, 2008:1). Niali dan hikmah yang dihasilkan akan membantu manusia untuk memecahkan yang dihadapi saat ini dan masa mendatang (Gottschalk, 2008:138).

Nilai dalam konteks pemeblajaran sejarah secara umum dapat bersumber dari: (1) peristiwa sejarah seperti nilai-nilai dalam peristiwa proklamasi, pertempuran medan area, rengasdengklok, atau peristiwa lainya; (2) peninggalan sejarah berupa artifact, mantifact ataupun sosiofact seperti manuskri, hikayat,serat,babad ataupun benda peninggalan sejarah lainya. Nilai tersebut dalam konstek pembelajaran sejarah merupakan bagian dari scafolding dan choaching yang membantu peserta didik dalam membangun makna dan pemahaman baru terhadap suatu obyek. Dengan demikian, nilai historis dan kultue bukan hanya memberikan latar bagi perkembangan koognitif infividu, tetapi lebih daripada itu niali-nilai tersebut juga memberikan simbol kultural atau perangkat psikologis bagi pembelajaran dan penalaran (Gredler, 2011: 396).

Berdasarkan paparan tersebut, sejarah berkontribusi dalam mengetahui dan memahami peristiwa di masa lampau ini berkontribusi terhadap perkembangan peserta didik, khusunya pada aspek kognitif dan afektif. Aspek kognitif mencakup pengetahuan kesejarahan (historical knowledge) dan keterampilan sejarah (historical skill) mengenai pengetahuan dan pemahaman konsep ataupunperistiwa di masa lampau (Gunning, 1978; Counsell, 2002) sementara itu, aspek afektif berkaitan dengan moral learning yang mengkonstruksi aspek emosional dan perilaku peserta didik dalam merefleksikan peristiwa di masa lampau dalam kehidupan kontemporer (Peterson, 2011).

Berdasarkan perspektif tersebut, pembelajaran sejarah idealnya mendorong individu untuk menganalisis, memahami dan menemukan permasalahan; dengan merekontruksi kembali 
dengan mengadopsi materi nilai-nilai historis dan kultural untuk membentuk sistem dan struktur yang lebih baik dan sesuai. Tujuan akhir dari pendidikan bukan semata-mata tercapainya internalisasi nilai atau penegtahuan. Akan tetapi menjangkau pada perubahan diri yang akan menjalar pada perubahan struktural.

\section{B. Pengertian Revolusi Industri 4.0}

Revolusi industri 4.0 sudah berada di depan mata, tidak terkecuali Indonesia. Konsep Revolusi Industri 4.0 ini merupakan konsep yang pertama kali diperkenalkan oleh Profesor Klaus Schwab. Beliau merupakan ekonom terkenal asal Jerman sekaligus penggagas World Economic Forum (WEF) yang melalui bukunya, The Fourth Industrial Revolution, menyatakanbahwa Revolusi Industri 4.0 secarafundamental dapat mengubah cara kitahidup, bekerja, dan berhubungan satudengan yang lain. Berikut ini empat tahapevolusi industri dari dahulu hingga kini.

1. Revolusi industri (1.0) yang pertama terjadi pada akhir abad ke-18. Hal ini ditandai dengan ditemukannya alat tenun mekanis pertama pada tahun 1784. Kala itu, industri diperkenalkan dengan fasilitas produksi mekanis yang menggunakan tenaga air dan uap. Peralatan kerja yang awalnya bergantung pada tenaga manusia dan hewan akhirnya digantikan dengan mesin tersebut. Akibatnya, meski jumlah produksi meningkat, banyak orang yang menganggur.

2. Revolusi Industri 2.0 terjadi di awal abad ke-20.Kala itu ada pengenalan produksi massal berdasarkan pembagian kerja. Produksi massal ini dimungkinkan dengan adanya listrik dan jalur perakitan. Lini produksi pertama melibatkan rumah potong hewan di Cincinnati, AmerikaSerikat, pada 1870.

3. Awal tahun 1970 ditengarai sebagai perdana kemunculan Revolusi Industri 3.0 yang dimulai dengan penggunaan elektronik dan teknologi informasi guna otomatisasi produksi. Debut revolusi industri generasi ketiga ditandai dengan kemunculan pengontrol logika terprogram pertama (PLC), yakni modem 084- 969. Sistem otomatisasi berbasis komputer ini membuat mesin industri tidak lagi dikendalikan manusia. Biaya produksi dapat ditekan oleh karena penerapan hal ini.

4. Awal tahun 2018 hingga sekarang adalah zaman revolusi industri 4.0. Industri 4.0 adalah industri yang menggabungkan teknologi otomatisasi dengan teknologi cyber. Ini 
merupakan tren otomatisasi dan pertukaran data dalam teknologi manufaktur. Pada era ini, industri mulai menyentuh dunia virtual, berbentuk konektivitas manusia, mesin dan data, semua sudah ada di mana-mana. Istilah ini dikenaldengan nama Internet of Things (IoT).

Seringkali kita mendengar istilah "Revolusi Industri 4.0”, sebuah istilah yang muncul dan dipopulerkan belakangan ini pada saat masyarakat dunia memasuki era milenium baru sejarah peradaban. Banyak orang sebetulnya masih tidak paham apa itu revolusi industri 4.0 dan kenapa mencantumkan angka 4.0 dibelakangnya. Kemudian bagaimana membedakan dengan revolusi pada tingkatan angkaangka sebelumnya? Dan pengaruhnya terhadap dunia pendidikan di Indonesia. Berikut sedikit ulasannya yang penulis susun dari berbagai sumber.

Industri 4.0 adalah nama trend dari sistem otomatisasi industri, dimana terdapat pertukaran data terkini dalam teknologi pabrik. Istilah ini mencakup sistem siber fisik, internet untuk segala aktifitas, komputasi kognitif dan aktifitas lain berbasis jaringan. Revolusi industri 4.0 sering pula disebut revolusi industri generasi keempat yang ditandai dengan kemunculan super komputer, robot pintar, kendaraan tanpa awak, editing genetik dan perkembangan neuroteknologi yang memungkinkan manusia dapat mengoptimalkan fungsi otak.

Mengutip penjelasan menteri perindustrian RI Airlangga Hartato tentang apa itu revolusi industri 4.0 dan latar belakang kehadirannya di Indonesia, beliau menjelaskan bahwa sejatinya revolusi industri pertama dimulai sejak jaman pemerintahan Hindia Belanda menduduki tanah air. Saat itu revolusi industri pertama hadir dalam koteks steam engine atau mesin uap untuk menggantikan tenaga manusia dan hewan.Revolusi industri kedua ditandai pada saat otomotif general fort membuat line produksinya di HindiaBelanda saat itu. Kala itu Industri otomotif ini berkembang pesat dan mendapat sambutan dari pemerintah Hindia Belanda. Revolusi ketiga diawali tahun 90-an dengan dimulai otomatisasi menjelang globalisasi. Globalisasi yang dikhawatirkan adalah lahirnya digitalisasi. Pada rapat APEC tahun 90-an disebutkan bahwa globalisasi untuk ASEAN bakal dimulai di tahun 2020. Revolusi industri keempat sendiri dimulai dengan revolusi internet, pemanfaatan internet of things pertama kali dilakukan oleh negara Jerman. Jerman pulalah yang mengglobalkan istilah industri 4.0 ke berbagai belahan dunia. 
Sejak tahun awal 2018 kita telah memasuki industri 4.0 yang ditandai meningkatnya konektivitas, interaksi dan batas antara manusia, mesin dan sumber daya lainnya yang semakin konvergen melalui teknologi informasi dan komunikasi. Pada revolusi industri keempat terjadi lompatan besar teknologi bagi sektor industri dimana teknologi informasi dan komunikasi dimanfaatkan sepenuhnya secara optimal. Tidak hanya dalam proses produksi saja melainkan juga di seluruh rantai nilai industri sehingga melahirkan model bisnis yang baru berbasis digital guna mencapai efisiensi yang tinggi dan kualitas produk yang lebih baik.

Revolusi industri generasi keempat iniditandai dengan kemunculansuperkomputer, robot pintar, kendaraantanpa pengemudi, editing genetik danperkembangan neuroteknologi yangmemungkinkan manusia untuk lebihmengoptimalkan fungsi otak. Hal inilah yangdisampaikan oleh Klaus Schwab, Founderdan Executive Chairman of the WorldEconomic Forum dalam bukunya TheFourth Industrial Revolution.

\section{Pembelajaran Sejarah Berbasis Digital Revelusi 4.0}

Pembelajaran tentang sejarah merupakan hal yang sangat penting, karena dengan mengetahui tentang sejarah maka kita bisa mengetahui tentang asal usul sebuah kejadian. Tetapi tidak semua orang senang belajar tentang sejarah, apalagi jika model pembelajaran hanya dengan membaca. Tentunya mengakibatkan kejenuhan dan keletihan yang dihadapi siswa.

Salah satu cara memperkenalkan dunia digital dalam pembelajaran sejarah adalah dengan cara tekonologi Digitalisasi. Teknologi digitalisasi mampu mempengaruhi watak seseorang dalam belajar serta mempengaruhi emosional dalam melaksanakan proses aktivitas belajar. Mahasiswa mampu melakukan aktivitas dengan daya tarik yang tinggi, hal ini salah satunya bisa di kembangkan dalam permainan atau Game, merupakan sebuah aktivitas rekreasi dengan tujuan bersenang-senang, mengisi waktu luang, atau berolahraga ringan. Permainan biasanya dilakukan sendiri atau bersama-sama (kelompok).

Salah satu Aplikasi yang dipilih dalam modelisasi digital kususnya dalam pembelajaran sejarah adalah, Role Playing Game (RPG), atau Visual Novel yang biasa digunakan dalam game petualangan, modeling ini di anggap sesuai dipilih sebagai bentuk dari pengembangan model

pembeladaran Story Telling berbasis Game edukasi. Sebagai bentuk implementasi dalam pembelajaran sejarah adalah tentang sejarah pejuang perempuan di daerah Aceh yaitu Cut Nyak Dhien, beliau adalah seorang pejuang perempuan yang berasal dari kerajaan Aceh Darussalam, dalam berperang melawan Belanda di Aceh. Dengan adanya modeling tersebut diharapkan 564 | Seminar Nasional Sejarah ke 4 Jurusan Pendidikan Sejarah Universitas Negeri Padang 
mahasiswa mampu meningkatkan semangat yang lebih tinggi serta menikatkan kreativitas dalam mempelajari pembelajaran sejarah.

\section{Peran Prodi Pendidikan Sejarah di Era Revolusi Industri 4.0}

Perkembangan ilmu pengetahuan dan teknologi begitu cepat telah mengubah dunia. Melihat yang terjadi saat ini, dunia telah memasuki revolusi industri generasi keempat. Hal tersebut sangat memerlukan peran perguruan tinggi kususnya pendidikan sejarah sebagai amunisi menghadapinya.

Revolusi Industri 4.0 atau Revolusi Industri Generasi Keempat adalah era yang ditandai dengan munculnya digital, superkomputer, robot pintar, editing genetik dan perkembangan neuroteknologi yang memungkinkan manusia untuk lebih mengoptimalkan fungsi otak. Tentunya konsekuensi yang akan dihadapi di era ini adalah bahwa pendidikan tinggi kususnya pendidikan sejarah harus berbenah untuk tidak lagi mengejar kuantitas tetapi yang paling penting adalah kualitas lulusannya.

Di era Revolusi Industri 4.0, mahasiswa harus berani keluar dari zona nyamannya selama ini. Fokusnya tidak lagi sekedar memiliki pengetahuan yang cukup tetapi harus memiliki keterampilan yang memadai, kompetensi manajerial, kemampuan kerjasama, kemampuan membangun jejaring yang luas, kemampuan mengadaptasi kemajuan teknologi informasi, dan keahlian lain yang mendukung lahirnya kreatifitas dan inovasi dalam kegiatan belajarnya dan tentu saja mampu menjawab tantangan zaman.

Mengenyam pendidikan di prodi pendidikan sejarah tidak hanya diarahkan pada tataran tobe (belajar menemukan jati diri),to know(belajar untuk tahu), dan to do(mengaplikasikan pengetahuan padakehidupan yang nyata) tetapi lebih dari itumenjangkau pada to live together (belajarmembentuk sikap hidup dalamkebersamaan). Sebagai mahasiswa adabeberapa hal yang harus dilakukan yaknimengasah kemampuan intelektual, aktifberorganisasi, meningkatkan skill, danmembangun sikap atau akhlak mulia danakan disiapkan untuk memiliki kemampuanliterasi data, literasi teknologi, dan literasimanusia.

Revolusi Industri 4.0 mengakibatkan terjadinya loncatan teknologi yang menyebabkan terjadinya perubahan yang sangat radikal begitupun halnya nanti akan terjadi perubahan dalam instruktional pembelajaran.Di masa depan kita akan menemui teknologi yang bisa menggantikan tenaga manusia. Oleh sebab itu, lapangan kerja di masa depan tidak akan hanya diperebutkan oleh masing-masing manusia tetapi manusia juga akan berlomba dengan mesin. Anda akan 565 | Seminar Nasional Sejarah ke 4 Jurusan Pendidikan Sejarah Universitas Negeri Padang 
bersaing dengan robot bukan dengan teman Anda, itulah masalahnya, bahwa musuh terbesar yang paling besar dalam diri kita adalah rasa takut serta rasa malas yang ada pada diri masingmasing. Lawanlah semua itu. Kita harus berani karena kita punya kelebihan. Kita adalah orang beriman, maka ada Allah tempat kita meminta.

Ketika mahasiswa ingin sukses, IPK yang tinggi dan lulusan perguruan tinggi yang bagus tidaklah cukup tetapi isu yang paling penting adalah bahwa mahasiswa tersebut perlu membentuk dirinya agar memiliki karakter antara lain adalah kejujuran, kedisiplinan, kepandaian dalam bergaul, bekerja keras dari yang lainnya, mencintai apa yang dikerjakan, kepemimpinan yang baik dan kuat, serta semangat dan kepribadian kompetitif.

Kemajuan dunia TIK mengubah banyak hal di dunia, pekerjaan yang bersifat rutin akan digantikan oleh kecanggihan teknologi internet of thing dan artificialintellegence. Akan banyak pekerjaan yang hilang, namun sebaliknya akan banyak pula peluang pekerjaan baru yang muncul. Kemajuan teknologi TIK juga merambah dunia perguruan tinggi hingga mengakibatkan perubahan luar biasa di semua disiplin ilmu. Oleh karena itu prodi pendidikan sejarah wajib berubah antara lain dengan mulai merumuskan kembali kurikulum yang kompatibel dengan tuntutan jaman, termasuk mulai mengubah proses belajar mengajar yang selama ini dilakukan, misalnya kuliah tidak hanya berupa tatap muka, namun bisa dilakukan secara daring, termasuk menyediakan co working space bagi mahasiswa dan dosen.

Perubahan juga diakibatkan karena mahasiswa dan calon mahasiswa kini adalah generasi $\mathrm{Z}$ yang merupakan digital native. Namun yang lebih utama, prodi pendidikan sejarah dituntut untuk meluluskan mahasiswa yang memiliki kemampuan adaptif terhadap perubahan yang makin sering terjadi. Kemampuan tersebut antara lain meliputi kemampuan menyelesaikan masalah yang makin kompleks, berpikir kritis, kreatif, mampu menjadi guru yang baik, sertamemiliki kemampuan koordinasi yang baik.Lulusan prodi pendidikan sejarah juga diharapkanharus punya emotional intellegence yangbaik, kemampuan menilai dan memutuskandengan tepat, berorientasi pelayanan, jagonegoisasi dan daya kognitif yang fleksibel, serta profesionalisme dalam bekerja.

\section{Simpulan}

Menghadapi era revolusi industri 4.0, peran Prodi pendidikan sejarah menjadi sangat penting, terutama dalam perkembangan ilmu pengetahuan dan teknologi. Oleh karenanya, 
pendidikan sejarah yang berbasis riset harus mendorong semakin terbukanya pengetahuan yang mampu meningkatkan kesejahteraan manusia. Revolusi industri 4.0 telah mengubah paradigma masyarakat dunia hari ini. Tuntutan untuk semakin meningkatkan inovasi di segala bidang terus menguat. Pasalnya, berbagai teknologi untuk menggantikan peran manusia di bidang industri semakin bermunculan. Hal itu memunculkan tantangan agar manusia hari ini bisa terus beradaptasi dengan perubahan zaman. Memasuki era revolusi industry 4.0yang berbasis digital,

pendidikan sejarahharus dikelola secara fleksibel tanpaterjebak rutinitas. Era tersebutmensyaratkan berbagai terobosanperguruan tinggi dalam menyiapkan sumberdaya manusia yang kompetitif.

Saat ini, yang menjadi tugas besar pemerintah adalah menyediakan pintu yang selebarlebarnya agar lebih banyak masyarakat yang bisa meraih pendidikan tinggi. Dengan begitu, kualitas sumber daya manusia dapat semakin kompetitif untuk menjawab kebutuhan zaman dan masa.

\section{DAFTAR PUSTAKA}

Arif Rahman Hikam.2013.Pengembangan Game Edukasi Berbasis Pembangunan Karakter Pada Materi Pelestarian Lingkungan.

Ali M.2010.Perancangan Game Edukasi Sejarah Sumpah Palapa Menggunakan Visual Novel

Brigtta Rena Estidianti dan Rahmatsyam Lakoro.2014.Perancangan Karakter Game Visual Novel "Tikta Kavya” Dengan Konsep Bishone.

Busran,Fitriyah.2015.Perancangan Permainan Edukasi Belajar Membaca Pada Anak Prasekolah Berbasis Smartphone Android.

Balasingham, K. (2016). Industry 4.0: Securing the Future for German Manufacturing Companies. Master'sThesis. University of Twente

Bonekamp, L., \& Sure, M. (2015). Consequences of Industry 4.0 on human labour and work organisation. J.Bus. Media Psychol, No.6, pp.33-40.

Dicky Jaya Umbara, 2013, Perancangan dan Pembuatan Edukasi untuk Pembelajaran Sejarah Kemerdekaan Indonesia menggunakan

Gotshcalk, L. (2008). Mengerti Sejarah, Jakarta: UI Press

Kochar. (2008). Pembelajaran Sejarah Teaching of History . Jakarta: PT Gramedia. 
Neugebauer, R., Hippmann, S., Leis, M., \& Landherr, M. (2016). Industrie 4.0-From the Perspective of Applied Research. Procedia CIRP, Vol. 57, pp. 2-7.

Nigappa, K., \& Selvakumar, J. (2016). Industry 4.0: A Cost and Energy efficient Micro PLC for Smart Manufacturing. Indian Journal ofScience and Technology, Vol. 9, Issue. 44. Undang-Undang Nomor 12 Tahun 2012 tentang Pendidikan Tinggi

Qin, J., Liu, Y., \& Grosvenor, R. (2016). A Categorical Framework of Manufacturing for Industry 4.0 and Beyond. Procedia CIRP, Vol. 52, pp.173-178. 